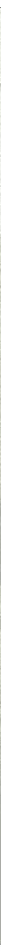

Bakgrunn: Sammenhengen mellom psykiske lidelser og rusmisbruk er godt dokumentert, men psykiatriske avdelinger har tradisjonelt fraskrevet seg ansvaret for pasienter med dobbeltdiagnose. Med rusreformen fikk rusmiddelmisbrukere pasientrettigheter på linje med alle andre pasienter, og reformen skulle bidra til å gi bedre tjenester og behandlingsresultater.

Hensikt: Å bidra til økt kunnskap om hvordan sykepleiere i psykiatriske avdelinger har erfart sin kliniske hverdag etter rusreformen.

Metode: Studien har et deskriptivt og eksplorerende design. Datainnsamlingen ble gjennomført i 2009 ved hjelp av fokusgruppeintervju med fire deltakere. Lydopptak av intervjuet ble transkribert i sin helhet og analysert i tråd med en fenomenologisk hermeneutisk metode.

Funn: Etter rusreformen har deltakerne erfart et økt fokus på rus, større pågang av pasienter som bruker rusmidler, samt at pasientgruppa ble bedre ivaretatt i de psykiatriske avdelingene. Samtidig opplevde de egen kunnskap i forhold til pasientgruppa som mangelfull, og mente i tillegg at kompetanseheving i forhold til rus ble nedprioritert. Mangel på behandlingsplasser, tid og personell var faktorer som bidro til en opplevelse av ikke å kunne gi pasientgruppen et tilfredsstillende tilbud.

Konklusjon: Endringene sykepleierne har erfart kan tolkes som en opplevelse av ikke å strekke til, hverken på system- eller individnivå.
Changes for nurses after the reform of health services for people living with substance abuse

Background: The correlation between mental illness and substance abuse is well documented. Traditionally, psychiatric wards have disclaimed the responsibility concerning patients who suffer from dual diagnosis. The substance abuse reform was meant to give people living with substance abuse the same rights as all other patients, and to contribute to better services and therapeutic results.

Objective: To contribute to increased knowledge on how nurses in psychi- atric wards have experienced their practice following the reform.

Methods: The study has a descriptive and explorative design. Data were collected in 2009 by focus group interviews of four individuals. The recorded interview was transcribed verbatim, and analysed using a phenomenological hermeneutic approach.

Findings: After the reform, the participants have experienced an increased focus concerning substance abuse, an influx of in-patients using substances and an improvement of dual diagnosis services in psychiatric wards. At the same time, they experi- enced a lack of knowledge regarding dual diagnosed patients, and claimed that competence elevation was downgraded. The lack of available services, time and personnel are all factors that contributed to a feeling of not being able to offer satisfactory services.

Conclusion: The changes the participants have experienced can be interpreted as a feeling of not being able to offer a satisfactory service, both as an individual and as part of a system.

Key words: nursing, health care, mental health, substance abuse, focus group, qualitative study 


\section{»Endringer i sykepleieres arbeid etter rusreformen}

Forfattere: Knut Tore Sælør og

Stian Biong

\author{
NøKKELORD \\ - Sykepleie \\ - Helsetjeneste \\ - Psykisk helse \\ - Rusmiddel \\ - Fokusgrupper \\ - Kvalitativ studie
}

\section{INTRODUKSJON}

Med rusreformen, som ble endelig iverksatt 1. januar 2004, overtok spesialisthelsetjenesten ansvaret for rusbehandling. Samtidig fikk rusmiddelmisbrukere pasientrettigheter på linje med andre pasienter. Reformen beskrives som betydelig, og skal bidra til å gi bedre tjenester og behandlingsresultater (1).

At psykiske lidelser og rusmisbruk ofte forekommer samtidig er godt dokumentert (2-5). Landheim, Bakken og Vaglum fant at 41 prosent av rusmiddelmisbrukere i rusmiddelbehandling tidligere hadde mottatt behandling $i$ psykisk helsevern (6). Fra psykisk helsevern er det funnet udekket behov for rusbehandling hos 51 prosent av pasientene som sliter med rusmiddelmisbruk i tillegg til sin psykiske lidelse (7). Samtidig har psykiatriske avdelinger ofte fraskrevet seg ansvaret for denne pasientgruppa. Pasientene har tilsynelatende ikke fått et tilfredsstillende tilbud hverken i russektoren eller psykiatrien, og har vært kasteballer mellom to separate systemer $(3,8-11)$.

I rusreformen pekes det på behovet for å styrke døgnbehandlingstilbudet til gruppen i det psykiske helsevernet. Samtidig skal reformen bidra til å redusere ansvarsfraskrivelse og gråsoneproblematikk, og man peker på behovet for å øke det faglige nivået i behandlingen (1).

\section{Teoretisk referanseramme}

Sammenhengen mellom alvorlige psykiske lidelser og rusmisbruk synes veldokumentert (3). Behandlingen av pasienter med dobbeltdiagnose har likevel i liten grad tatt utgangspunkt i kunnskap man har fra feltet (2). Samtidig har det vist seg vanskelig å dokumentere hvorvidt ett tiltak har bedre effekt enn andre (12). Mueser, Noordsy, Drake, og Fox (4) er blant dem som tar til orde for et integrert behandlingssystem, og hevder denne tilnærmingen kan eliminere ulempene ved sekvensiell (å behandle den ene lidelsen før den andre) eller parallell behandling (rusproblemet og den psykiske lidelsen behandles parallelt hos ulike behandlere). I stedet adresserer samme behandler eller behandlingsteam begge tilstandene samtidig, og forståelsen av hvordan den psykiske lidelsen og rusmisbruket påvirker hverandre står sentralt. Forfatterne understreker at integrert behandling bare vil være effektiv dersom den omfatter behandlingskomponentene integrasjon, mangfoldighet, aktivt oppsøkende tiltak, redusering av negative konsekvenser, langsiktighet, motivasjonsbasert behandling og ulike psykoterapeutiske behandlingstilbud. Også Evjen, Boe Kielland og Øiern (3) argumenterer for integrert behandling, og presiserer i likhet med ovennevnte forfattere at denne må nyanseres i forhold til hvilke psykiske lidelser det gjelder. Tidligere studier i

Hva tilfører denne artikkelen? Studien kan tyde på at sykepleiere opplever at de yter et bedre tilbud til pasienter med dobbeltdiagnose etter rusreformen. Samtidig har de fått oppgaver de ikke opplever seg faglig rustet til å løse.

\section{Mer om forfatterne:}

Knut Tore Sælør er sykepleier med mastergrad i klinisk helsearbeid. Han arbeider som spesialsykepleier ved Utredningsseksjon for Unge, Psykiatrisk avdeling, Lier, Klinikk for psykisk helse og rus, Vestre Viken HF. Stian Biong er sykepleier med doktorgrad i folkehelsevitenskap og ansatt som førsteamanuensis ved avdeling for helsefag, Høgskolen i Buskerud. Kontakt: knut.tore. saeloravestreviken.no 
Norge av behandlingsforløp hos personer med rusmisbruk og psykisk lidelse har også vist at behandlingen må være sammensatt av mange komponenter og tilpasses den enkeltes behov (13).

Det som i artikkelen omtales som «rusreformen» består i realiteten av to Odelstingsproposisjoner $(1,14)$. Her omtales disse for enkelhets skyld i entall. Med psykiatriske avdelinger menes ulike døgnposter på spesialisthelsetjenestenivå. Klinisk hverdag refererer til det arbeidet som til daglig utføres av sykepleiere i tverrfaglige team i ulike psykiatriske avdelinger. Dette inkluderer samhandling med pasienter, andre faggrupper og samarbeidspartnere utenfor sykehusavdelingene. Begrepet dobbeltdiagnose er som regel brukt der pasienten har en alvorlig psykisk lidelse kombinert med et omfattende rusmisbruk (3). Betegnelsen er til dels omstridt (3,15-18), men er valgt fordi den sammenfaller med terminologien som oftest benyttes i spesialisthelsetjenesten.

Flere evalueringer, undersøkelser og tilsyn er gjennomført i den hensikt å vurdere om målsettingene i reformen er innfridd (1921). Videre er reformen hyppig omtalt i faglitteratur og offentlige publikasjoner. På tross av dette finner vi gjennom litteratursøk lite forskning som behandler sykepleieres opplevelse av hvordan rusreformen påvirker deres kliniske hverdag. Både som premissleverandører og fagutøvere utgjør sykepleierne en viktig del av dagens tverrfaglige helsevesen. Skal samarbeid, kompetanse og holdninger bedres må alle aktører inkluderes. Hensikten med studien er derfor å bidra til økt kunnskap om hvordan sykepleiere i psykiatriske avdelinger erfarer sin kliniske hverdag etter rusreformen. For å belyse problemstillingen er følgende forskningsspørsmål utarbeidet: Hvordan opplever sykepleiere i psykiatriske avdelinger at deres kliniske hverdag har endret seg etter rusreformen?

\section{METODE}

Bruk av kvalitative metoder er hensiktsmessig der problemstillingen er sammensatt og med et mangfold av potensielle svar (22). Samtidig brukes kvalitative studier ofte i den hensikt å øke oppmerksomheten og forståelsen av et fenomen som fra før er lite utforsket (23). Da problemstillingen i liten grad er beskrevet tidligere fikk studien et deskriptivt og eksplorerende design.

\section{Utvalg}

For å ivareta en god gruppedynamikk $(22,24)$ ble sykepleiere som i størst mulig grad hadde samme arbeidsoppgaver og ansvarsområde $\mathrm{i}$ avdelingene invitert til å delta. I tillegg måtte eventuelle deltakere ha jobbet ved psykiatriske avdelinger lenge nok til å ha erfart hvilken påvirkning rusreformen hadde hatt $\mathrm{i}$ egen klinisk hverdag.

I utgangspunktet meldte seks deltakere seg til studien. På kort varsel måtte to melde avbud. Av hensyn til de andre deltakerne ble datainnsamlingen gjennomført som planlagt. De fire deltakerne besto av én kvinne og tre menn. De hadde arbeidserfaring som strakk seg fra året før reformen ble iverksatt, til 25 års erfaring fra psykiatriske avdelinger. Da intervjuet ble gjennomført var de ansatt ved tre ulike sykehusavdelinger på et sykehus i østlandsområdet. For å sikre deltakerne konfidensialitet beskrives ikke ytterligere karakteristikker.

\section{Etiske overveielser}

Studien ble meldt til Person- vernombudet for forskning, og godkjent 01.04.09. Deretter ble det aktuelle sykehus kontaktet. I samråd med avdelingsledere presenterte en av forfatterne (KTS) studien for mulige deltakere, samtidig som et informasjonsskriv ble distribuert ved de aktuelle avdelingene. Tre av deltakerne meldte sin interesse gjennom kontaktpersoner ved avdelingene. Den fjerde tok kontakt via e-postadressen $\mathrm{i}$ informasjonsskrivet.

Deltakerne sikres konfidensialitet ved at sitater eller uttalelser ikke kan knyttes til bakgrunnsinformasjon. Data er oppbevart og slettet i henhold til personvernombudets retningslinjer. Det ble innhentet skriftlig informert samtykke ved starten av datainnsamlingen, og deltakerne var kjent med at de til enhver tid kunne trekke seg fra prosjektet uten negative konsekvenser. Etter gjennomføringen av datainnsamlingen ble deltakerne oppfordret til å ta kontakt dersom de skulle ha behov for dette.

\section{Datainnsamling}

Datainnsamlingen ble gjennomført ved hjelp av et engangs fokusgruppeintervju (heretter kalt intervjuet) med KTS som moderator. Metoden ble valgt fordi den er egnet til å gi mye materiale der hensikten er å undersøke felles erfaringer. Gruppeprosessen bidrar til å få fram nyanser og bredde i dataene, men dette forutsetter en aktiv og åpen moderator som ivaretar deltakerne og sørger for at alle kommer til orde $(22,24)$.

For å få fram deltakernes subjektive opplevelser og bidra til god gruppedynamikk ble intervjuet innledet med studiens forskningsspørsmål som åpningsspørsmål. Moderator tilrettela deretter for en gruppediskusjon gjennom å stille oppfølgende og 
utdypende spørsmål, og ved å henvende seg til alle deltakerne. Samtidig var det moderators oppgave å fokusere intervjuet (25). På forhånd var stikkordene samarbeid, kompetanse og holdninger notert som mulige oppfølgingstema. Intervjuet ble tatt opp på lydbånd.

\section{Analyse}

Lydopptaket av intervjuet ble transkribert i sin helhet og analysert i tråd med en fenomenologisk hermeneutisk metode (26). Metoden tar utgangspunkt i Ricoeur's fortolkningsteori (27). Målsettingen er å utarbeide en helhetsforståelse av meningen i datamaterialet gjennom en analyse i tre trinn.

Innledningsvis formuleres førsteinntrykket av teksten - den naive forståelsen. Denne skal i størst mulig grad være fri for egne fortolkninger og benytte et fenomenologisk språk nærmest mulig deltakernes eget. Den naive forståelsen leder veien videre i arbeidet, og skal valideres av temaene som utarbeides i trinn to. I trinn to, den strukturelle analysen, blir meningsbærende enheter i teksten markert. Dette kan være en del av en setning, en setning, flere setninger eller et avsnitt som uttrykker kun én mening. Disse blir først kondensert og så kategorisert i undertema. Undertemaene blir nærmere vurdert og abstrahert i temaer. I trinn tre uttrykkes en helhetlig forståelse av temaene i relasjon til hele teksten. Analyseprosessen harmonerer godt med beskrivelsen av den hermeneutiske spiral, der man pendler mellom helhet, del og ny helhet (28).

\section{FUNN}

\section{Naiv forståelse}

Deltakerne beskrev økt fokus på rusmisbruk i avdelingene etter at reformen ble iverksatt. Det var flere pasienter med rusmisbruk innlagt enn tidligere, og noen deltakere sa de hadde fått bedre rutiner rundt håndtering av rusbruk, og i større grad enn før møtte pasientene med respekt. Enkelte opplevde at dette gikk på bekostning av pasienter som ikke var rusmisbrukere, blant annet ved at behandlingsplasser hadde gått tapt ved opprettelsen av nye avdelinger for pasienter med dobbeltdiagnose. Deltakerne beskrev at nye ressurser ikke ble tilført, men flyttet fra et sted til et annet. Dessuten mente delta- kerne at de ikke hadde nok alternative tilbud å erstatte rusbruk med, for eksempel tilstrekkelig med aktiviteter. De hadde også måttet omstille seg i forhold til å tenke mer langsiktig i forhold til pasientene. Dette opplevde de som utfordrende på grunn av tidspress. Flere beskrev at de opplevde behandlingen som lite sammenhengende. Dette mente de skyldes for få behandlingsplasser både på sykehuset og $\mathrm{i}$ kommunene. Deltakerne beskrev egen kompetanse på området som mangelfull, og ønsket å lære mer. Samtidig mente de at kompetanseutvikling i forhold til rusmisbruk ble nedprioritert, noe de tilskrev lokal ledelse.

\section{Strukturell analyse}

Den strukturelle analysen resulterte i fire tema (se eksempler i tabell 1).

\section{Bedre ivaretatt}

Flere av deltakerne opplevde at pasienter med dobbeltdiagnose ble bedre ivaretatt på psykiatriske avdelinger nå enn før reformen. Det ble blant annet pekt på at pasientgruppa hadde fått flere rettigheter, samt at kunnskap og rutiner rundt rus-

TABELL 1: Eksempler fra den strukturelle analysen (trinn to).

\section{Meningsbærende enhet}

Der også så skorter det jo litt på vår kunnskap, da. Hva slags oppfølging er det mest riktig å tilby? Han kommer ut i kommunen og når ikke de heller sitter inne med siste viten så kan det jo bli litt, om ikke tilfeldig, så i hvert fall ... dårlig, altså av lite kompetanse.

De kursene som jeg har deltatt på, de har jeg fått gjennom kontakter ute, ikke gjennom min egen avdeling. De kursene som jeg blir tilbudt, de er sånne ... tradisjonelle. Implementeringa av rus i psykisk helse, den er fremdeles ikke helt oppe og går, det er litt for mye gamle ting i veggene til at vi slipper helt taket.

\section{Kondensert meningsbærende enhet}

Dårlig tilbud henger sammen med mangel på kunnskap og lite kompetanse om riktig oppfølging både i sykehuset og i kommunen.

Kontakter ute informerer om kurs som oppleves som relevante. Kurs som tilbys gjennom avdelingen erfares som for tradisjonelle. Nye utfordringer møtes på gamle måter. Implementering av rus betyr å slippe taket i det gamle.

\begin{tabular}{|c|c|}
\hline Undertema & Tema \\
\hline $\begin{array}{l}\text { Mangel på } \\
\text { relevant kompe- } \\
\text { tanse. }\end{array}$ & $\begin{array}{l}\text { Usikkerhet } \\
\text { om hvordan } \\
\text { man skal } \\
\text { tilby helhet- } \\
\text { lig behand- } \\
\text { ling. }\end{array}$ \\
\hline $\begin{array}{l}\text { Ansattes egen } \\
\text { vurdering } \\
\text { av behov for } \\
\text { kompetanse og } \\
\text { ny kunnskap } \\
\text { nedprioriteres. }\end{array}$ & $\begin{array}{l}\AA \text { være lite } \\
\text { verdsatt. }\end{array}$ \\
\hline
\end{tabular}


problematikk hadde blitt bedre. Også holdningene opplevdes som endret etter reformen: "Jeg ser at vi møter folk med mye større grad av respekt, vi har akseptert at dette er en del av vår hverdag ... vi ser at tilbakemeldingene fra pasientene er bedre enn før. Vi er på vei mot et bedre, holistisk syn på den pasientgruppa.»

\section{Mangel på ressurser}

I dette tema inngikk beskrivelser av mangel på behandlingsplasser, tid og personell som hinder $i$ behandlingen. På tross av ulikheter mellom disse tre faktorene, har de til felles å bli erfart som mangler på systemnivå. Særlig så det ut til at mangelen på behandlingsplasser opptok deltakerne, noe de opplevde kunne gi brudd i behandlingskjeden: «Vi må be dem om det mest håpløse i verden; å dra hjem å vente. Det er tre måneders ventetid. Det er jo det samme som, ikke bare tilbakefall ... da står du der.»

Tidspress og fokus på effektivitet ble også opplevd som utfordrende: «Du får ikke avdekka hva som er psykiatri, og hva som er russymptomer på den korte tida et sånt opphold er, så det er stort sett bare rusen vi ser.»

\section{Helhetlig behandling}

Utfordringer knyttet til hvilken behandling man skal tilby pasientgruppa var noe alle deltakerne hadde erfart, og var sammen med forrige tema det som tok mest plass i fokusgruppa: «Det er for dårlig kunnskap om hvordan man skal hjelpe de med rus, rett og slett». En av deltakerne mente at man for lett tyr til medisiner i møte med angst og depresjon, og flere trakk frem aktiviteter som en viktig del av behandlingstilbudet. Samtidig beskrev flere utfordringer i behandlingsrelasjonen: «Jeg vet ikke om folk vegrer seg på grunn av pasientrettigheter eller hva, men man lar dem rett og slett sove for mye noen ganger.» Den kanskje tydeligste og mest grunnleggende usikkerheten vedrørende behandlingstilbudet kom til uttrykk slik: «Jeg vet ikke om vi er egnet engang jeg, som system, for å ivareta deres behov. Kanskje vi kan komme inn når de har fått dem nyktre? De har fremdeles en tilleggslidelse som er psykisk helse, og så må vi ta det derfra.»

\section{Lite verdsatt}

Følelsen av å være lite verdsatt var noe deltakerne hadde opplevd: «Vi må bryne oss på gamle tradisjoner fremdeles. Fremdeles er den beste sykepleieren den som tar psykisk helse». Samtidig var opplevelsen av å bryne seg på gamle tradisjoner noe de også beskrev på vegne av pasientgruppa. Når begge perspektivene inkluderes i samme tema er det fordi deltakerne argumenterte for at de hang sammen. I diskusjonen rundt nedprioritering av ruskompetanse uttalte en av deltakerne: «Jeg tror det handler mye om holdinger ... fremdeles er det holdninger som regjerer, til den pasientgruppa. Fordi det er en annen måte å jobbe på, det er andre utfordringer, og det er andre typer verdier og verdigrunnlag. Man må på en måte akseptere andre menneskers måte å leve på.»

\section{Helhetsforståelse}

Med bakgrunn i egen forforståelse, forskningsspørsmålet, den naive forståelsen og de ulike temaene fra den strukturelle analysen ble følgende helhetsforståelse av tekstens innhold formulert: Rusreform - nye utfordringer, og en opplevelse av ikke å strekke til.

\section{DISKUSJON}

Hensikten med studien er å bidra til økt kunnskap om hvordan sykepleiere i psykiatriske avdelinger erfarer sin kliniske hverdag etter rusreformen.

Uavhengig av syn på organisering av behandlingstilbudet er det slik at samtlige deltakere har opplevelser knyttet til usikkerhet eller uenighet rundt hvordan man kan tilby adekvat behandling til pasienter med dobbeltdiagnose, og hva den bør inneholde. Skretting (9) påpeker nettopp at organisatoriske endringer i tjenestetilbudet ikke gjør noe med mangelen på ruskompetanse i psykisk helsevern. En strukturreform blir ikke automatisk en innholdsreform. Empirien i vår studie tyder på at holdningen til pasientgruppa er positivt endret, til tross for at deltakerne opplevde å ha for dårlig kunnskap om rusmisbruk. Relevant kompetanseutvikling på området ble nedprioritert, noe deltakerne satt i sammenheng med at holdningene til pasientgruppa fortsatt må forbedres. Beskrivelser av mangel på kompetanse og behov for opplæring kan vi finne både i norsk (29) og internasjonal litteratur $(5,30)$. Vi tror ledere i større grad må erkjenne hvilke faglige, ressursmessige og holdningsmessige utfordringer pasienter med dobbeltdiagnose representerer for sykepleiere. Det ser ut til å være behov for mer målrettet arbeid for å gi sykepleiere den kompetansen de mener de trenger. Men det er også nødvendig å gi dem en opplevelse av at kunnskap knyttet til rusmisbruk er verdsatt.

Deltakernes beskrivelser av egen klinisk hverdag samsvarte i stor grad med utfordringene tilknyttet pasienter med dobbeltdiagnose som gjennom en årrekke har vært presentert i offentlige publikasjoner (18,31-33). Dette var noe av det som overrasket oss i analysen av empirien. Stikk- 
ordene samarbeid, kompetanse og holdninger, som hadde blitt notert til diskusjon før gjennomføringen av intervjuet, ble uoppfordret brakt på banen i intervjuet av deltakerne. Empirien tyder på at behandling av pasienter med dobbeltdiagnose fortsatt ser ut til å by på særlige utfordringer for sykepleiere i psykiatriske avdelinger.

Helse- og omsorgsdepartementet slo i 2001 fast at basiskravene til kvalitetssikring bør være de samme i psykisk helsevern som deltakerne $\mathrm{i}$ vår studie. I disse dager er nye nasjonale retningslinjer for utredning, behandling og oppfølging av personer med en samtidig alvorlig psykisk lidelse og ruslidelse i ferd med å bli sluttført. Retningslinjene skal bidra til oppklaring og trygghet for helsepersonell, pasienter og pårørende: «Ruslidelser og psykiske lidelser henger ofte sammen. Derfor skal tjenesteytere ha god kunnskap om begge tilstander. Utredningen og diagnostiseringen skal gjøres ved hjelp av standardiserte verktøy,

\section{Det er for dårlig kunnskap om hvordan man skal hjelpe de med rus, rett og slett.}

$\mathrm{i}$ institusjoner for rusmiddelmisbrukere (10). Men rusreformen $(1,14)$ sier lite om hva innholdet $\mathrm{i}$ behandlingen bør være, eller hvordan den bør organiseres. Moen påpeker (34), med utgangspunkt i legers erfaringer, at på tross av strengere krav til kvalitetssikring har rusreformen i liten grad ført til enighet om behandlingen av rusavhengighet. Dette ser ut til å være en beskrivelse som også passer for deltakerne i vår studie. Å tilby integrert behandling er én måte å ivareta pasientgruppen $\mathrm{i}$ psykiatriske avdelinger på. Dette forutsetter kjennskap til prinsippene for en slik organisering av behandlingen, samt kunnskap om ulike tilnærminger som kan passe den enkelte (13). Skal man lykkes med dette må også ledere ha et ønske om å integrere rusbehandling $\mathrm{i}$ tilbudet på psykiatriske avdelinger, og man må gi tilbud om opplæring $(4,35)$.

En litteraturstudie hevder at det nå er på tide med handling, og ikke retorikk, i forbindelse med den aktuelle pasientgruppa (36). Dette er et poeng som ser ut til å være relevant også for og den psykiske lidelsen og ruslidelsen skal behandles helhetlig og individuelt» (37). Det ser ut til at hverken en stortingsmelding (18), et rundskriv (10) eller rusreform $(1,14)$ har gitt deltakerne i vår studie tilfredsstillende svar på hvordan et integrert behandlingstilbud til pasienter med dobbeltdiagnose bør se ut. Kanskje er det for ambisiøst å forvente at retningslinjer skal gjøre det? Det kan se ut til at faglige og ideologiske motsetninger uansett gjør det vanskelig å komme til enighet omkring hvordan et behandlingstilbud til pasientgruppen bør og skal være utformet.

Nye retningslinjer resulterer neppe i flere behandlingsplasser, bedre tid eller mer personell. Likevel kan man håpe at retningslinjene bidrar til å skape et tydeligere innhold i behandlingen av pasienter med dobbeltdiagnose, og sier noe om hvilke tilnærminger det kan være fruktbart å velge i møte med den enkelte. Kanskje kan resultatet bli at kompetanseutvikling i større grad prioriteres, og at sykepleiere etter hvert føler seg mer kompetente i møte med pasientgruppa? Skal man lykkes må retningslinjene forplikte og engasjere på alle nivå. Sykepleiere må få anledning til å bli kjent med og diskutere dokumentet, og ikke minst må ledere gi anledning til å følge det opp. Slik kan retningslinjene kanskje bidra til å redusere opplevelsen av ikke å strekke til i utfordringene knyttet til behandling av pasienter med dobbeltdiagnose.

\section{Metodologiske overveielser}

Studiens styrke er å belyse sykepleieres erfaringer fra klinisk hverdag etter rusreformen, noe som tidligere ikke har vært gjenstand for noen systematisk undersøkelse. Dette bidrar til å gjøre funnene relevante.

Samtidig har studien flere begrensninger. Vi kunne presentert et bredere teoretisk perspektiv. Det er heller ikke grunn til å hevde at ett fokusgruppeintervju med fire deltakere representerer hverdagen til samtlige sykepleiere på psykiatriske avdelinger. Flere deltakere, fra flere sykehus, eller bruk av flerstegsfokusgruppeintervju, ville ha gitt mer data. Etter å ha gjennomført datainnsamlingen antok vi likevel at vi hadde nok materiale til å besvare forskningsspørsmålet. Dessuten hadde deltakerne, med sine erfaringer fra ulike psykiatriske avdelinger, innblikk i en kultur og hverdag som berører flere enn deltakerne selv. Med utgangspunkt i studiens vitenskapsteoretiske antakelser vil funnenes overførbarhet til syvende og sist være opp til den enkelte leser å vurdere.

\section{KONKLUSJON}

Veien fra vedtak om rusreform til endringer i den kliniske hverdagen for sykepleierne i psykiatriske avdelinger synes lang. Deltakerne opplevde likevel at de yter et bedre tilbud til pasienter 
med dobbeltdiagnose etter rusreformen. Samtidig har de fått oppgaver de ikke opplever seg faglig rustet til å løse, og mener det mangler ressurser for å kunne gi tilfredsstillende hjelp til pasientgruppa. Resultatet av endringene

\section{REFERANSER}

1. Sosialdepartementet. Om lov om endringer i lov 13. desember $1991 \mathrm{nr} .81$ om sosiale tjenester m.v. og i enkelte andre lover (Statlig overtakelse av deler av fylkeskommunens ansvar for tiltak for rusmiddelmisbrukere). Ot.prp. nr. 3 (20022003). 2003.

2. Ringen, PA. Substance use in psychotic disorder. Use patterns and relation to clinical and cognitive characteristics in schizophrenia and bipolar disorder Doktoravhandling. Oslo: Det medisinske fakultet, Universitetet i Oslo, 2008.

3. Evjen R, Boe Kielland K, Øiern T. Dobbelt opp. Om psykiske lidelser og rusmisbruk. Oslo: Universitetsforlaget, 2007.

4. Mueser KT, Noordsy DL, Drake RE, Fox L. Integrert behandling av rusproblemer og psykiske lidelser. Oslo: Universitetsforlaget, 2006

5. Rassool, Hussein (Red.). Dual Diagnosis Nursing. Oxford: Blackwell Publishing Ltd, 2006

6. Landheim AS, Bakken K, Vaglum P. Sammensatte problemer og separate systemer. Psykiske lidelser blant rusmisbrukere til behandling i russektoren. Norsk Epidemiologi 2002;12:309-18.

7. Gråwe RW, Ruud T. Rus og psykiske lidelser i psykisk helsevern for voksne. Oslo: Sintef Helse, 2006

8. Kunnskapssenteret. Dobbeltdiagnose alvorlig psykisk lidelse og ruslidelse. Del 2 Effekt av psykososial behandling. Rapport nr 25-2008. Oslo: Nasjonalt kunnskapssenter for helsetjenesten, 2008.

9. Skretting A. Fra klient til pasient. Vil den norske rusreformen gi rusmiddelmisbrukere et bedre behandlingstilbud? Nordisk Alkohol- \& Narkotikatidsskrift 2005:22:125-40.

10. Helse- og omsorgsdepartementet. Tjenester til mennesker med psykiske lidelser og omfattende rusmiddelmisbruk. Rundskriv, I-36/2001. 2001.

11. Askey, Jane. Dual diagnosis: a challenging therapeutic issue of our time. Drugs and Alcohol Today 2007;7(4): 33-9

12. Cleary M, Hunt GE, Matheson SL, Sigfried N, Walter G. Psychosocial interventions for people with both severe mental illness and substance misuse (Review). Cochrane Database of Systematic Reviews 2008, Issue 1. Art. No.: CD001088. DOI: 0.1002/14651858.CD001088.pub2. kan forstås som en opplevelse av ikke å strekke til, hverken på system- eller individnivå. Studiens implikasjon er å peke på behovet for en grundig diskusjon av kunnskapsgrunnlaget og det faglige og ideologiske grunnsynet i behand-

13. Vaglum P. Psychopathology and Substance Abuse: Clinical Lessons from six Norwegian Studies. Psychiatric Fennica 1996;27:55-67.

14. Sosialdepartementet. Om lov om endringer i lov 13. desember $1991 \mathrm{nr} .81$ om sosiale tjenester m.v. (Rusreform II og rett til individuell plan). Ot.prp.nr. 54 (2002-2003). 2003.

15. Rusbehandling Midt-Norge. Rus/ psykiatriproblematikk: Hvordan sikre god behandling, samhandling og kompetanse i spesialisthelsetjenesten Helse Midt-Norge? Stjørdal: Rusbehandling Midt-Norge, 2005

16. Todd J, Green G, Harrison M, Ikuesan BA, Self C, Baldacchino A, Sherwood S. Defining dual diagnosis of mental illness and substance misuse: some methodological issues. Journal of Psychiatric and Mental Health Nursing 2004;11:48-54.

17. Drake RE, Essock SM, Shaner A, Carey KB, Minkoff K, Kola L, Lynde D, Osher FC, Clark RE, Rickards L. Implementing Dual Diagnosis Services for Clients With Severe Mental Illness. Psychiatric Services 2001:52:469-76.

18. Sosial- og helsedepartementet. Åpenhet og helhet. Om psykiske lidelser og tjenestetilbudene. St.meld. nr. 25 (19961997). 1997.

19. Lie T, Nesvåg S. Evaluering av rusreformen. Rapport IRIS - 2006/227. Stavanger: International Research Institute of Stavanger, 2007.

20. Lie T. Evaluering av den statlige rusreformen for brukere i Oslo kommune. Rapport IRIS - 2006/228. Stavanger: International Research Institute of Stavanger, 2007.

21. Helsetilsynet. Oppsummering av landsomfattende tilsyn i 2006 med tverrfaglige spesialiserte tjenester til rusmiddelmisbrukere. Rapport fra Helsetilsynet 2/2007.

22. Malterud K. Kvalitative metoder i medisinsk forskning. Oslo: Universitetsforlaget, 2003

23. Polit DF, Beck CT. Nursing Research. Generating and Assessing Evidence for Nursing Practice. Philadelphia, USA: Lippincott Williams \& Wilkins, 2008.

24. Kitzinger J. Qualitative Research: Introducing focus groups. British Medical Journal 1995; 311:299-302.

25. Kvale S, Brinkmann S. Interview. ling av pasienter med dobbeltdiagnose $i$ avdelingene.

Vi ønsker å takke sykepleierne som giennom sin deltakelse gjorde det mulig å giennomføre studien.
Introduktion til et håndværk. København: Hans Reitzels forlag, 2009.

26. Lindseth A, Norberg A. A phenomenological hermeneutical method for researching lived experience. Scandinavian Journal of Caring Sciences 2004;18:14553

27. Ricoeur P. Fortolkningsteori. København: Vintens Forlag, 1979.

28. Thornquist E. Vitenskapsfilosofi og vitenskapsteori for helsefag. Bergen:

Fagbokforlaget, 2003.

29. Cappelen TP. Psykisk helsevern: dobbeltdiagnosepasienter - en interessant målgruppe for sykepleiere! Tidsskriftet sykepleien 2004:92:34-8.

30. Hughes E, Wanigaratne S, Gournay K, Johnson S, Thornicroft G, Finch E, Marshall J, Smith N. Training in dual diagnosis interventions (the COMO Study): Randomised controlled trial. BMC Psychiatry 2008;8 (12) http://www.biomedcentral. $\mathrm{com} / 1471-244 \mathrm{X} / 8 / 12$

31. Norges offentlige utredninger. Fra stykkevis til helt. En sammenhengende helsetjeneste. NOU 2005:3. Oslo: Statens Forvaltningstjeneste, 2005.

32. Sosial- og helsedirektoratet. ... OG BEDRE SKAL DET BLI! Nasjonal strategi for kvalitetsforbedring i sosial- og helsetjenesten (2005-2015). Veileder IS-1162. 2005.

33. Helse- og omsorgsdepartementet. Samhandlingsreformen. Rett behandling - på rett sted - til rett tid. St.meld. nr. 47 (2008-2009). 2009.

34. Moen SH. Behandling av rusmiddelavhengighet sett $\mathrm{i}$ lys av rusreformen 2004 - en gjøkunge i helsevesenet? Hovedoppgave. Bergen: Det psykologiske fakultet, Universitetet i Bergen, 2008

35. Brunette MF, Asher D, Whitley R, Lutz WJ, Wieder, BL, Jones, AM, McHugo, GJ. Implementation of Integrated Dual Disorders Treatment: A Qualitative Analysis of Facilitators and Barriers. Psychiatric Services 2008;59:989-95.

36. Edward KL, Munro I. Nursing considerations for dual diagnosis in mental health. International Journal of Nursing Practice 2009:15:74-9.

37. Helsedirektoratet. Psykisk 0409. Oslo: Helsedirektoratet, 2009.

Les kommentaren på side 177 》 